(235)

\title{
How Bio-physical Impacts of Campsite-Use affect Camping Experiences at Highly- visited National Parks of Sri Lanka
}

Mallikage S.T.*, Perera P.K.P., Wettasinghe S.A.

\author{
Department of Forestry and Environmental Science, University of Sri Jayewardenepura, Sri Lanka \\ *shashinitara@yahoo.com
}

\begin{abstract}
With escalating demand for wildlife tourism in Sri Lanka's National Parks, the visitor interest on camping in designated campsites inside National Parks is also on the rise. However, unplanned recreational uses such as camping in natural areas can induce significant and often localized resource impacts that can affect soil, vegetation, wildlife, and water, with severity of such impacts varying depending on the intensity of use. Limited or no published research have attempted to assess the camp-site users' perceptions on bio-physical impacts of campsite use in the Sri Lankan context. Therefore, this study evaluated the campers' perception on environmental impacts of campsite use in highly-visited National Parks in the dry zone of Sri Lanka. Campsite user characteristics, visitor motivations, behaviors and how visitor experience is affected by visible biophysical impacts at campsites were evaluated using a structured questionnaire. The survey also gathered management actions perceived by campsite users to minimize such environmental impacts. The questionnaire was administered over-the-phone with a total of 202 individuals who had a camping experience within a period of less than 12 months from the date of contact, responding to the survey (response rate of $56.1 \%$ ). Results revealed that "to be in a natural setting" as the main motivation for camping in National Parks while wildlife viewing and photography were the most popular activities of campers. Well-educated middle-aged males dominated the camping visitor segment. Based on the visitor behaviors and underlying visitor motivations derived through a Factor Analysis, the study further identified three distinct segments of campsite users: Eco-tourists, Prestige seekers, and Adventure seekers. Results further indicated that presence of litter, vandalism activities, vehicle related impacts and current solid waste disposal practices in campsites are negatively affecting visitor experience. Respondents in general, especially the well-educated high income visitor segment exhibited environmentally responsible behaviors during camping. With respect to visitor perceptions on future management of campsites, respondents approved management measures aimed at assuring the ecological integrity of campsites while disapproving substantial infrastructure development within campsites. Study results overall highlights the importance of managing biophysical impacts in campsites to provide a high quality visitor experience, while sustainably managing tourism activities in National Parks. Potential management implications are further discussed.
\end{abstract}

Keywords: Wildlife tourism, Camping, Recreation ecology, Campsite user survey, Ecotourism 